\title{
Everyday Citizenship in Village Java
}

\author{
Takeshi Ito
}

Citizenship has gained currency as a key concept in the global strategy to promote and deepen democracy. For a strong and well-functioning democracy, the argument goes, ordinary people should be willing and able to participate in the decision making process that affects their lives as rights-bearing citizens. For donors and international aid agencies leading this democracy drive, 'traditional' and 'vertical' social relations - including patron - client relations - are deemed to be incompatible with democracy. Subjects need to be transformed into rights-bearing citizens. Citizenship, understood in this manner, is often uncritically linked to specific configurations of institutions and framed within the rhetoric of liberal democracy, with political and civil rights that realize citizen participation and deliberation. Perhaps, because of this normative bias, there is a relative dearth of research on the actual experience and practice of citizenship. A bulk of the literature on citizenship focuses on the normative attributes of citizenship such as the legal status and rights of citizens, but less on the form and nature that citizenship actually takes in postcolonial countries (Robins et al., 2008; Cornwall et al., 2011; see this volume's Introduction).

Citizenship can be understood as a relational process, shaped by everyday interactions between state and citizen (Chatterjee 2004; Holston 2008; Lund 2011). While the actual forms of citizenship in developing countries like Indonesia remain far from the normative ideal of liberal democracy, we cannot simply dismiss such 'deviations' as 'democratic deficits.' Instead, citizenship needs to be studied not only in terms of citizenship rights and duties, but also in terms of how these rights and duties actually shape and are shaped by everyday state - citizen interactions. In practice, citizenship rights and status are often weakly enforced, to the particular detriment of weaker groups such as women, minority communities, and the poor. Despite the emphasis on the institutional domain of citizenship, the weaker groups are tenuously linked to the state through it. In other words, as this article argues, the everyday forms of village citizenship is not so much bound by the institutional domain of citizenship but rather by personal relations with immediate power holders in their community.

In Indonesia, since the Reformasi era (1998 - present), new democratic institutions such as the direct elections of the president, regional and village 
heads, village council and participatory development planning were established as part of the democracy drive to fix the broken linkage between elected officials and citizens. ${ }^{1}$ At the same time, these new democratic institutions were accompanied by a host of new democratic concepts - emany of them are English-loaned words - asuch as demokrasi (democracy), desentralisasi (decentralization), otonomi daerah (regional autonomy), partisipasi (participation), transparansi (transparency), and akuntabilitas (accountability). Despite the foreign origins and technical nature, however, these words have been used, often without local translations or further explanations, in local government regulations, guidelines and political campaigns at the local level. With the introduction of the democratic institutions and language, villagers are expected to act like citizens by using their rights to participate in the decision-making process and to deliberate policies and issues that affect people's lives.

However, the new institutions and language are not automatically translated into the democratic practice of citizenship rights and duties framed by the language of liberal democracy. At the village level, these new institutions and language are also being adapted to the day-to-day process of local politics. Crucially, in this process, they do not replace old actors and institutions, but rather are integrated into the existing institutions of power (Bierschenk and Olivier de Sardan 2003). In other words, the integration of new institutions into the existing institutions of power creates layers of power where new institutions of power sediment on the old layers of power. Thus, the everyday form of citizenship is mediated at the village level where the institutional domain and logic of citizenship integrate with the local logics and processes of power relations. For instance, while the rural poor in village Java are expected to realize their citizenship by incorporating these new democratic institutions in their day-to-day activities, they might find little usefulness or benefit in doing so because the rural poor's ability to make use of the new institutional framework is mediated and shaped by the layers of power.

This article explores state - citizen interactions in democratizing Indonesia with a focus on the role of village officials in linking villagers to the state and its impact on the extent of citizenship for the rural poor. The focus on the role of village officials in democratization is important because they are the

1 The democratization process has been full of twists and turns. A major setback occurred in September 2014 when the House of Representatives (DPR) passed Law No. 23/2014 on Regional Government that annulled the direct elections of governors, regents, and mayors. A few days later, then President Yudhoyono issued two government regulations in lieu of law (Perppu) to save the direct elections of regional heads. In January 2015, the House approved the two government regulations, and reinstated the direct elections of regional heads. 
most immediate formal and informal institutions that directly shape the local forms and experiences of citizenship. To what extent does the institutionalization of citizenship as rights and legal status transform the existing forms of patronage politics and clientelistic relations in society? How is citizenship perceived, experienced, and practiced by elites as well as by the rural poor? How do different degrees of their understanding of citizenship give shape to the everyday practice of citizenship?

The everyday form of citizenship is tightly linked to political strategies of the poor. While the establishment of rights, legal status and citizenship regime depend primarily on state capacity, the everyday form of citizenship is contested and remade by interactions between various actors with varying degrees of access to power and resources through formal and informal institutions such as rights, voices, and clientelism. As will be examined, the everyday form of citizenship that the rural poor experience is not shaped by how well citizenship rights are defined, but by how the rural poor engage in politics to get by every day, including clientelistic relations with immediate power holders in their community. This article narrates and situates stories of everyday citizenship experienced by the rural poor in a Javanese village, and explores the complex relation between clientelism, citizenship and democracy by working back from these stories (Robins et al., 2008:1082). These stories suggest that the rural poor perceive, experience, and practice citizenship in a manner quite different from the ideal-type of an autonomous, engaged, rights-claiming citizen. By taking this disjuncture as a lead, this article traces the origins of layered citizenship in the tenuous linkage between state and citizen deeply embedded in a particular trajectory of state formation in Java.

To understand why the rural poor are tenuously linked to the state, the next section examines a particular trajectory of state formation that left intact formal and informal power structures side by side. In doing so, it attempts to shed light on the close relationship between state formation and postcolonial citizenship in the historical context of Java and to provide an analytical tool to make sense of what is going on in terms of the rural poor's relationship with village elites.

\section{State, Property and Citizenship}

Indonesia's citizenship regime is highly layered and differentiated. While the law stipulates that every Indonesian citizen has the same rights, citizenship is particularistic, shaped by power relations rooted in social category, identity, class and property. This means that citizenship is a relational process, shaped 
by everyday interactions between state and citizen. The character of these interactions is shaped by trajectories of state formation (Introduction to this volume; Mamdani 1996; Tilly 2004; Schulte Nordholt 2005; Van Klinken 2009; Cornwall et al., 2011). State formation in this context is not only a top-down process of extension of state domination, legalization of privileges and entitlements, and invention of social categories and traditions. State formation is also a bottom-up process of increasing citizen/subject participation in state affairs. This increased involvement evolves through local elites who broker interactions with state institutions, functioning as a lubricator between state and society (Hirsch 1989; Agrawal 2001; Ito 2011). Crucially, in this process, informal structures of power are not necessary absorbed and eliminated, but rather coexist next to formal state institutions. The manner in which state agents establish the legitimacy of state power and impose consent on local people through local elites gives rise to particularistic exchanges of benefits through personal relations marked by patronage and clientelistic practices. As a result, the rural poor in Java were always tenuously linked to the state. They have been incorporated into the state's domain through village elites as a source of labour and the target of rural development. In this process, the village office acting as the interface between state and village has played an important role as a basis of patronage for village elites, and in return they recognized the state's legitimacy of extracting a surplus from the peasants.

How and why did bureaucratic office become an important source of power and material benefits in Indonesia? In his landmark work Indonesia: The Rise of Capital, Richard Robison explored the origins of the weak indigenous capitalist class in Java. Among the three major factors he analysed, two are particularly useful for us: (1) the relative weak institutionalization of private property in pre-colonial society and (2) the persistence, under colonial rule, of political appropriation as the basis for accumulation (Robison 1986:11). The relatively weak institutionalization of private property has roots in the nature of power in pre-colonial Javanese kingdoms. Pre-modern states in Java were far more interested in concentrating their subjects at the core within relatively easy reach, rather than occupying land. 'Mataram Kingdom', writes Ong Hok Ham (1975:45), 'was largely an agrarian state with very little money economy. As a result, relations between king and bupati (regent) were in terms of patron client relationships. In the same way, the bupati's control within the region was based on martial alliances and personal ties with lower priyayi and important villagers'. In other words, the core of a kingdom's rule revolved around control over people through king's charisma, personalized rule and reciprocity based on patron - client relations.

Kingdoms' emphasis on labour rather than land continued under Dutch indirect rule. In colonial Java, state power extended to peripheries by 
formalizing the superior ability of the priyayi (members of the local nobility) to control local people as holders of bureaucratic office. In this process, establishing the village as the lowest administrative unit constituted the essential part of state formation (Breman 1980). 'From 1830 onwards,' writes Robison (1986:14), 'the priyayi were progressively integrated into the machinery of the colonial state and divested of their traditional rights of tribute from the peasantry'. For these intermediaries, land ownership was of little importance for the basis of their economic and political power. Rather, it was access to state power and material benefits associated with bureaucratic office that provided an important source of local economic and political power. Thus, when the colonial state offered the land grants of 1830 , the priyayi turned down the opportunity to legalize their access to land. Instead they chose to maintain power by becoming salaried agents in the colonial state. ${ }^{2}$ Given the weak institutionalization of private property, the priyayi preferred instead to nurture their relation with the colonial state as it provided a more secure source of income.

In sum, this trajectory of state formation through intermediary powers left intact formal and informal power structures side by side. Due to the weak institutionalization of private property, bureaucratic office rather than land provided the basis of patronage for the local nobility and village elites. ${ }^{3}$ For a large part, people's encounter with the state was through intermediaries including village officials whose duty was to collect dues and later to provide a host of other services including social welfare to villagers in the form of rural development. Village office was inheritable at that time, which made village officials immune to pressures from ordinary villagers. From their end, ordinary villagers depended on village elites to interact with the state and its myriad laws, rendering their relationships paternalistic.

This mediated model of the state - citizen relationship was solidified under Suharto's New Order regime (1966-1998). The developmentalist bureaucratic state rendered society disengaged from politics, and mobilized national resources to accelerate economic development. With the windfalls of oil revenue in the 1970s, the Indonesian state developed vast clientelistic networks that distributed benefits and largesse to rural intermediaries in return for political support (Hart 1989; Antlov 1995; Schiller 1996). At the top of this large

2 Robison (1986:11-2) ably put it, 'One of the most crucial developments in the colonial period was the failure of the Javanese priyayi to transform their traditional rights of appropriation over land, labour and produce into rights of private ownership on a large scale.'

3 Conventionally in Southeast Asia the patron depended more on the local organization of force than hereditary status or land ownership. In the nineteenth century, the penetration of colonial government and commercialization of the economy transformed the traditional basis of patron - client relations to land ownership (Scott 1972:101). 
clientelistic pyramid stood President Suharto, from where people, money, and goods moved downwards to support village elites (Antlov 1995). While the clientelistic networks and practices helped the state distribute material benefits, they also came to constitute the primary logic of state - village interactions.

Furthermore, the Indonesian state reduced various forms of village government structures that had remained illegible into the standardized unit of political control. Law No. 5/1979 on Village Government was issued with the stated objectives of 'standardization, demobilization, mono-loyalty, and depoliticization.' The rigid structure of village government helped the Indonesian state realize the virtuous circle of social demobilization, political stability, and economic development. Under the tutelage of the Indonesian state, the village head enjoyed numerous material benefits associated with the position as long as he managed to return the favour by supporting the central government in implementing national development projects and mobilizing villagers to vote for the government party Golkar during elections. In other words, the village head as the enforcer of the central government represented the interest of higher authorities rather than that of villagers. Thus, it was through the vast clientelistic networks and the standardization of village government structures that the Indonesian state was able to extend its reach and to strengthen its control over villages.

With the fall of Suharto's authoritarian regime in May 1998, the clientelistic networks and practices that had characterized the state - village relationship during the New Order era was brought under the critical eyes of experts. The Reformasi era (1998-present) saw the proliferation of foreign aid for democratic institutional reform. ${ }^{4}$ Particularly, the village government structure has been at the centre of the democratic institutional reform. To make a break, the past policies, laws No. 22/1999 and No. 32/2004 on regional government were enacted with the new key words 'diversity, participation, autonomy, democratic, and empowerment' with the aim of democratizing village government. The next section details the experiences of citizenship by the rural poor, relying on

4 Particularly notable here is the significant level of support from donors, international organizations and international charitable foundations to deepen and consolidate democracy. Between 2000-2005, for example, there are 217 governance reform projects in Indonesia, involving twenty-two foreign donor agencies (such as the World Bank, the United Nations Development Programme, the Asian Development Bank, the Netherlands, Denmark, Australia, et cetera) and fifty-eight foreign implementing agencies (e.g. the Asia Foundation, Oxfam-GB, et cetera) (Edi and Setianingtias 2007). These governance reforms focus on several primary areas of governance such as 'civil service reform' (18\%), 'anti-corruption' (17.5\%), 'decentralization' (11.5\%), 'law and legal reform' (9.5\%) and 'civil society empowerment' $(7 \cdot 5 \%)$. Figures in parentheses indicate the percentage of the total number of projects. 
my fieldwork in Bandung District, West Java, conducted between 2004-2005 which was followed up by subsequent multiple visits.

\section{Citizenship in the Rural Periphery of the Priangan Highlands}

Situated on a hillside of the Priangan highlands of West Java, a half-an-hour ride on a country road connecting the village to the central market and a cluster of textile factories in Majalaya, is a rural village that I call Namiwari. ${ }^{5}$ In 2008, 8,785 people lived in the village. Agriculture is a main source of livelihoods for the majority of villagers. On the north part of the village is mostly agricultural land. A stream flowing into the Citarum River provides an important source of water for most paddy fields. Landowning farmers, sharecroppers and agricultural labourers cultivate land for rice, cabbage, peppers, eggplants and carrots. In irrigated rice paddy fields, farmers rotate the cultivation of land with freshwater fish. Sharecropping is still practiced; the local sharecropping system called maro divides harvest in half between landowners and sharecroppers.

Rural villages in the Priangan highlands have been polarized by landownership. Unlike Central Java where communal land possession of paddy fields inhibited the process of land concentration, the Priangan highlands saw the development of heritable individual possession (Kano 1977:15), making the problem of land concentration and landlessness particularly acute. According to an early study of land ownership in Java, by the early twentieth century, one-third of the agrarian population was landless while $9 \%$ of owners $(5 \%$ of the total population) owned over 2 bahu (1.4 hectare) of farmland (Husken and White 1989:40). In order to ameliorate the impacts of landlessness, the Dutch colonial government promoted non-farm employment by creating a major textile production centre in Majalaya.

The problem of landlessness, however, continued to plague the livelihoods of the majority of farmers in Namiwari. Between 1948 and 1962, the Priangan highlands were affected by the Islamic State (Darul Islam) movement. To protect themselves from raids, villagers in Namiwari moved to central Majalaya and elsewhere. As people who had evacuated for safety began to return to the village in the 196os, population pressures on land were increasingly felt. In 1967, population density in Majalaya sub-district as a whole was 1,888 square kilometre and landless peasants accounted for $46.7 \%$ of the total households (Matsuo 1970:62-63). The trend of increasing landlessness in the village continued throughout the 1980 s and 1990s. By 2003, the number of landowning

5 I use a pseudonym to protect the anonymity of the villagers. 
households in Namiwari was 396 or one-fifth $(20.3 \%)$ of the village population. As a result the average cultivated area per household in Namiwari declined from 0.66 hectare in 1967 to 0.55 hectare in 1980 to 0.41 hectare in 2003 . To sustain a family, villagers modestly say, at least one hectare of farmland is required. The average farmland of 0.4 hectare means that the average farmer cannot sustain a family through farming alone. To supplement incomes, many villagers work at textile factories near central Majalaya. Villagers also attend family-run kiosks for snacks and street vendors.

Against this background, development has long been conceived of gifts rather than of rights by both village elites and ordinary villagers. During the New Order era, the government planned and implemented intensive rural development projects to build key infrastructures such as roads, irrigations, schools and health posts and to distribute agricultural credits for seeds, fertilizers and pesticides in the countryside. Because of the clientelistic ties with the state, village elites gained disproportionately large benefits from the implementation and management of these rural development projects. ${ }^{6}$ Village elites invested these gains in agribusiness, transportation business and their children's education to maintain their privileged status within the village.

This is also evident in Namiwari where two influential families have dominated the village office (desa), alternatively taking the position of the village head. ${ }^{7}$ They have managed to control the flows of material benefits from the national and local governments, and distributed them to villagers in a clientelistic manner. Cece, the first village head (in office 1983-1994) and a son of the village police, began his career like his father as the village policeman in 1968. When Namiwari separated from Wonosari in 1983, he was appointed as the acting village head by the sub-district government and then elected by villagers as the village head in 1986. He appointed his family friends in key posts in the village office (desa) such as village divisions (dusun), community and neighbourhood associations, irrigation associations (mitra cai), family welfare groups ( $\mathrm{PKK})$ and youth groups (karang taruna). During his tenure, Cece was entitled to 2 hectare of village land, ${ }^{8}$ which he rented out to his family friends as sharecroppers, and enjoyed privileged access to rural development

6 Elsewhere in Java, Husken (1991) showed that a tightly knit network of elite kin ties in a Central Javanese village allowed few village elites to establish a basis for controlling both local political power and economic resources.

7 Desa in Indonesian literary means 'village'. In day-to-day conversations at Namiwari, both village elites and ordinary villagers use desa to refer to the village office in general, which includes the building, staff and functions of village government.

8 Village officials have also similar privileged access to village land of smaller size. 
funds via the district government. To ensure the smooth flows of rural development funds, however, he had to pass government-imposed electoral thresholds for his village at elections by mobilizing his villagers and collecting votes for the government party Golkar. Power and benefits associated with the village head enabled him to accumulate capital. While in office, he purchased a mini bus, and began the operation of passenger transport. ${ }^{9}$ He hired friends of the family, including his village officials, to operate his passenger transportation business. Cece could also send his son Kartiwa to high school in Majalaya. ${ }^{10}$

In the Reformasi era, two major institutional changes were introduced to fix the broken linkage between village officials and ordinary villagers. First, following the implementation of Law No. 22/1999 on regional government, the village representative council (Badan Perwakilan Desa) was established in 2000 in Namiwari. The village council was expected to heed the voices of ordinary people and check the power of the village head. The village council regulation No. 1 says, 'the village council has the responsibility, function and authority to abide by the rules, to monitor village government, and to respond to villagers' needs'. The second significant institutional change was that, in 2003, as part of the conditionality of the World Bank's local governance reform project, the Bandung District government introduced a new mechanism of development planning called the Consultation on Planning of Annual Development Activities (МРКт). This consultation mechanism enabled villagers to have a say in prioritizing village development projects to be approved and funded by the district government. In other words, the newly introduced participatory planning promotes in theory direct participation by all villagers of all social differences in village development meetings and incorporates villagers' voices in the design and implementation of development projects. In theory, this new mechanism of participatory planning could thus curtail the existing practice of redistributing benefits to a minority of village elites and their friends in a clientelistic manner. ${ }^{11}$

These newly established institutions received mixed responses from village elites and ordinary villagers. For village elites, the village council performs its responsibility, and contributes to democracy. Although he moved to Namiwari relatively recently, Engkos was elected to the inaugural chair of the village

9 Over the years, he successfully added more vehicles and now owns six mini buses.

10 In Namiwari, high school education is considered as a high achievement. Because of his education background and his father's influence, Kartiwa was later elected as village head in 2002 at the age of forty.

For the mechanism of participatory planning, see Ito (2006). 
council. ${ }^{12}$ When asked about his institution's performance, he replied, 'Yes, we have democracy in the village. Although villagers' participation is not maximum, that is not a problem because their interests are now represented by the village council.' He believes that in the context of village democracy, while direct participation by villagers is preferable, it is perfectly substitutable for representation because the village council can deliberate on their behalf. For him, whether or not villagers participate and deliberate is not important.

When asked about the performance of the village council, however, a fairly significant number of villagers complained about a lack of any significant change in village government. They did not feel that the village office was any closer to them now. Instead, most villagers agree on the absence of the state in the village in the Reformasi era. They complain that district, sub-district, and village officials rarely 'come down' (turun) to their neighbourhoods to make contacts with them. ${ }^{13}$ Some villagers jokingly said, 'I do not even know who our village councillors are.' Suryadi, a village division head (kadus), offered a pessimistic observation on the performance of the village council. 'The village council is just a name. When the members are elected into office, they do not go anywhere. They just sit there. [The council] represents the voices of few. Villagers know the council members only by their names, and do not turn to them even when they want to express their concerns about village affairs. ${ }^{14}$

Similarly, ordinary villagers do not see the new mechanism of participatory planning as pro-poor. The village office (desa) claimed that in 2004 village development meetings were held and attended by many villagers. Yet of those villagers I interviewed almost no one - except villagers close to desa - knew about this participatory planning. In fact, desa neither made participatory planning known to villagers nor invited ordinary villagers to village development meetings. As in the past, invitation letters were sent only to recognized, male individuals - religious leaders, village elders and holders of village office. Moreover, village officials hardly appear to care about holding meetings at

12 Although he is not from the influential families, he was elected because of his progressive social activities in a non-governmental organization working on governance reform in Majalaya, his religious activities as a respected Islamic teacher, and his relatively higher educational background.

13 When village officials visit communities ( $\mathrm{RW}$ ) and neighbourhoods ( $\mathrm{RT}$ ), it is symbolically described as 'come down' (turun) to indicate the invisible hierarchy or divide between village officials and ordinary villagers.

Interview with village district head (kepala dusun), August 2006. 
times when villagers who work during the day could attend. Thus most villagers never participated in the participatory planning process nor brought their requests to desa.

Otong is an agricultural labourer and has not participated in village meetings before and after the introduction of the participatory planning mechanism. Otong found it rather hard to participate in formal village meetings because of his less than adequate educational background. Village meetings are normally conducted in Bahasa Indonesia, but Otong is unable to speak the official language because he did not graduate from elementary. Yet, this lack of qualifications does not appear to be the main obstacle. Otong further explains his non-participation: 'Generally, I do not disagree on decisions made by desa. What matters to me is results. I am fine as long as desa brings about the results of development.' Otong is concerned not with the rights and power that the new institutions might provide to ordinary villagers like him. He cares about what desa can offer. His social and economic situation forces him to value immediate benefits rather than status and rights to participate and deliberate. In other words, the everyday form of citizenship is tightly linked to political strategies that prioritize tangible benefits over abstract ideals.

This lack of participation by the rural poor, however, does not mean that they are not interested in development. Normally, they have a long wish list of things that they need to have improved. Some of the things on their list include building and improving village roads necessary to connect hard-to-reach hamlets to the main road for agricultural and commercial activities, improving the performance of village government services such as the issuance of the healthcare cards, improving irrigation to cope with droughts, or building houses for widows and Islamic schools for children.

Eti, a mother of ten children, moved to Namiwari in the early 199os. She has neither participated in village meetings nor brought any requests to desa for consideration. She and her husband do not have permanent jobs, but work as agricultural labourers. The wages for a day of work in rice paddy fields are barely enough for the family - 10,00o rupiah (one us dollar) for the husband and 6,500 rupiah ( 0.65 us dollar) for her. Rice can be harvested three times a year; they receive thirty kilograms of unhusked rice for each harvest. She brings their unhusked rice to a mill owned by former village head Cece. She pays two litres of rice for the service of milling 30 kilograms of rice. When asked why she avoids political engagement with desa, Eti ably explained:

...I feel ashamed of asking for help, and am afraid of village officials. They rarely come down to our hamlet; nor do I go up to desa. I just remain 
quiet rather than vocal (diam saja dari pada bilang). What is more important is that the stomach is filled and I sleep well (perut diisi tidur enak).

It is ironic that ordinary villagers do not see the village council or participatory planning as a democratic institution that can fix the broken linkage between village officials and ordinary villagers. Like Eti, the rural poor are working hard just to get by every day. Their concern is not democratic decision-making and their inclusion as rights-bearing citizens. They want tangible improvements of the quality of their lives, including better state services and a raise of the salary that they receive from their employers. The arenas of participation and deliberation are interpreted and guarded by intermediary powers who have linked village to state. From Eti's account, it is clear that the rural poor find little use in realizing their demands through political engagement with desa because desa refuses to interact with the rural poor on an equal footing and to come to terms with their real situation. For the rural poor, good or pro-poor officials are those who recognize them and make life a little easier for them. When rights and legal status inscribed in law do not enable the rural poor to improve their situations, the rural poor have more to expect from clientelistic exchanges with well-to-do neighbours and village elites.

Yet, when the needs of Namiwari's poorer villagers are not met, they do act independently of village officials. On a sunny morning in the monsoon season, over forty villagers, young and old, but mostly women, gathered to build a narrow paved path connecting a hamlet to the village main road. ${ }^{15}$ It was a community project organized by two well-to-do villagers, and implemented by neighbours to make it easy to transport harvested agricultural products to the markets and commute to central Majalaya. One of the well-off organizers was Sofyan, a retired former employee of the National Telecommunication Company (Telkom) who manages a public phone store (wartel) and a kindergarten in the village. The other organizer was Koko, a retired local official of Bandung's agricultural department who owns 4 hectare of land in a nearby sub-district. ${ }^{16}$ They run a village Quran reading group in their hamlet. Both organizers lamented that villagers had long wished this paved-path to be built by the village office, but that the latter done virtually nothing to improve the condition of their hamlet. They took the matter to their own hands. They supplied construction materials worth five million rupiah (five hundred us

\footnotetext{
15 A villager explained that men were absent because they were in the fields attending their crops.

16 In the late 196os, he was sent to study at Leiden, the Netherlands as part of his training by the Indonesian government.
} 
dollar), while their neighbours provided the labour. On that day, Eti and her husband also helped making the paved path. The efforts of the volunteers' work was rewarded by a hot meal prepared by women at the house of a village official. The meal was a local (Sundanese) dish - rice with cooked vegetables donated by the two organizers.

On the one hand, this kind of volunteerism can be seen as a sign of strong communal bonds and social capital. On the other hand, the tradition of community voluntarism has reified clientelistic, hierarchical relations. Since the colonial times, the village office has always relied on a combination of forced labour or community volunteerism to perform the operation of day-to-day village responsibilities, some of which fall into the realm of the government such as building village infrastructure and Independence Day celebrations. Today, village officials create the village budget based on the assumption that community volunteering is an important asset. The village budget is composed of three kinds of revenue: transfer from the district government, the village's own revenue and community volunteering (swadaya masyarakat) which is monetized. ${ }^{17}$ Because a larger share of community volunteering makes a good impression - cooperative, proactive and thick social capital - on the higher administration, desa makes efforts to mobilize volunteers by emphasizing the duties of villagers. In the eyes of desa, villagers are expected to perform certain duties as the recipient of development benefits. In this sense, the experience of everyday citizenship suggests that ordinary villagers might be low on rights but high on duties.

This high expectation of duties for ordinary villagers, contrasted with negligible emphasize of rights, has had significant influence over the actual practice of citizenship at the village level. The formal process and rights stipulated in the local regulations and guidelines for participatory planning are in practice interpreted to fit the village elites' perception of citizenship for the rural poor. There is a clear sense of class-based division between them in terms of who can and who cannot participate and deliberate in the decision-making process. Institutional changes have not made significant dents in the paternalistic attitude of village elites that goes back to colonial times and which was fostered through their intermediary role in making village communities eligible to the state as the eyes and ears of the state. Representative and participatory procedures appear to build on these earlier forms of patron - client relations. During informal conversations with village secretary Deden who hails from one of the influential family lineages in the village, he shared a phrase his father (former village head during the New Order era) used to remind himself of

17 In the 2004 budget, community volunteering accounted for $21.6 \%$ of the village budget. 
the role of the village office: 'Who are we? Whom do we serve? Where are we heading to? At the end of the day, we return to our original goal of serving for villagers.' Beneath the surface of political correctness, this phrase illuminates the invisible and indelible social division between village officials and ordinary villagers, closely aligned with the earlier forms of patron - client relations rooted in the particular trajectory of state formation in the context of Java.

\section{Conclusion}

This article has shown the local complexity of everyday citizenship in village Java. As seen above, citizenship is far from universal, and institutional configurations, rights, and legal status have had little impact on how the rural poor in Namiwari perceive, experience and practice citizenship in their everyday life. Rather, this article began with a premise that the tenuous linkages between villagers and the domain of the state suggest that the everyday form of citizenship that villagers experience is not bound by rights and legal status, but more tightly by personal relations with immediate power holders in their community. Thus, the everyday form of citizenship is tightly linked to political strategies of the rural poor that prioritize tangible benefits over abstract ideals. The rural poor employ various strategies and tactics of rights, voices and clientelistic protection because they experience citizenship in relations of power. Agricultural labourers Otong and Eti's disengagement from desa might appear to reflect simply a wrong understanding of citizenship rights and duties and even a lack of interest in democratic citizenship on their part.

Institutional change is not easily changing this layered form of citizenship because such mediated relations are a product of state - society interactions over a long period of time. Viewed from a vantage point of the historical development of state formation, the everyday form of village citizenship is rooted in the manner in which the budding colonial state expanded its power over villages. In colonial Java, because of the weak institutionalization of private property, it was not through landownership but rather through access to desa that rural elites established the basis of their power. In other words, state formation proceeded by co-opting village elites into desa while at the same time making the position of village head hereditary to ensure village elites' access to state resources in return for recognizing the state's legitimacy. It was thus through desa that village elites have accumulated rural power by serving as the interface between state and villagers, while rural power was not replaced by rationalizing state power but rather sedimented during the process of state formation. 
In postcolonial Indonesia, this dialectic relationship was further reinforced by rendering desa as the unit of political control through the standardization of village government structures. The imposition of the standardized form of village government did not replace the existing institutions of power, but created layers of power where new institutions of power sediment on the old layers of power. In a similar way, institutional change aimed at nurturing citizenship under the democratic reform of the Reformasi era must navigate through the layers of power accumulated and sedimented over the historical course of institutional change imposed from above. Thus, far from being straightforward and of institutional rationale, local politics is characterized by power relations, which in turn make the everyday form of citizenship that ordinary villagers experience as a relational process.

Citizenship in village Java is fluid and elusive. Therefore, the institutional view of citizenship falls short of capturing the still image of everyday citizenship. Instead of pursuing a universal shape of citizenship, this article has narrated and situated the stories of everyday citizenship experienced by the rural poor in village Java. While this article by no means rejects the normative attributes of citizenship as an important part of understanding citizenship, such a focus has failed to recognize the various ways in which people perceive, experience, and practice citizenship beyond the institutional domain. Rather, it is through working back from stories of people's experiences, this article suggests, that we can capture the everyday form of citizenship from the vantage point of ordinary citizens.

\section{References}

Agrawal, A. (2001). State formation in community places? Decentralization of control over forests in the Kumaon Himalaya, India. The Journal of Asian Studies, 6o(1), 9-40.

Antlov, Hans. (1995). Exemplary Centre, Administrative Periphery: Rural Leadership and the New Order on Java. Surry: Curzon.

Bierschenk, T. and J.P. Olivier de Sardan. (2003). Powers in the Village: Rural Benin Between Democratisation and Decentralisation. Africa, 73(2), 145-173.

Breman, Jan. 1980. The Village on Java and the Early-Colonial State. Rotterdam: Erasmus University Rotterdam Comparative Asian Studies Programme.

Chatterjee, P. (2004). The Politics of the Governed: Reflections on Popular Politics in Most of the World. New York: Columbia University Press.

Cornwall, A., S. Robins and B. Von Lieres. (2011). States of Citizenship: Contexts and Cultures of Public Engagement and Citizen Action. IDS Working Paper 363 . 
Edi, J. and A. Setianingtias. (2007). Donor proliferation and donor coordination Indonesia: the case of governance reform. Paper prepared for Centre for the Future State, Institute of Development Studies, University of Sussex.

Hart, G. (1989). Agrarian change in the context of state patronage. In G. Hart, A. Turton and B. White, (Eds.), Agrarian transformations: local processes and the state in Southeast Asia (pp. 31-49). Berkeley, CA: University of California Press.

Hirsh, P. (1989). The state in the village: interpreting rural development in Thailand. Development and Change, 20(1), 35-56.

Holston, J. (2008). Insurgent citizenship: disjunctions of democracy and modernity in Brazil. Princeton: Princeton University Press.

Husken, F. (1991). Power, property and parentage in a Central Javanese Village. In F. Husken and J. Kemp (Eds.), Cognation and social organization in Southeast Asia. Leiden: KITLV Press.

Husken, F. and B. White. (1989). Java: Social Differentiation, Food Production, and Agrarian Control. In G. Hart, A. Turton, and B. White (Eds.), Agrarian transformations: local processes and the state in Southeast Asia (pp. 235-265). Berkeley, CA: University of California Press.

Ito, T. (2006). The Dynamics of Local Governance Reform in Decentralizing Indonesia: Participatory Planning and Village Empowerment in Bandung, West Java. Asian and African Area Studies, 5(2), 137-183.

Ito, T. (2011). Historicizing the power of civil society: a perspective from decentralization in Indonesia. Journal of Peasant Studies, 38(2), 413-433.

Kano, H. (1977). Land tenure system and the desa community in nineteenth century Java, Tokyo: Institute of Developing Economies.

van Klinken, G. (2009). Patronage democracy in provincial Indonesia. In O. Tornquist, N. Webster, and K. Stokke (Eds.), Rethinking popular representation (pp. 141-159). Hampshire: Palgrave Macmillan.

Lund, C. (2011). Property and citizenship: conceptually connecting land rights and belonging in Africa. Africa Spectrum, 46(3), 71-75.

Mamdani, M. (1996). Citizen and subject: contemporary Africa and the legacy of late colonialism. Princeton: Princeton University Press.

Matsuo, H. (1970). The development of Javanese cotton industry. Tokyo: Institute of Developing Economies.

Onghokham. (1975). The residency of Madiun: pryayi and peasant in the nineteenth century. Ph.D. Dissertation. Yale University.

Robins, S., A. Cornwall and B. von Lieres. (2008). Rethinking citizenship in the postcoloy. Third World Quarterly, 29(6), 1069-1086.

Schiller, J. (1996). Developing Jepara in New Order Indonesia. Clayton: Monash Asia Institute. 
Schulte Nordholt, H. 2005. Decentralisation in Indonesia: less state, more democracy? In J. Harriss, K. Stokke and O. Tornquist, eds. Politicising democracy: the new local politics of democratisation. Hampshire: Palgrave Macmillan.

Scott, J. (1972). Patron-client politics and political change in Southeast Asia. American Political Science Review, 66(1), 91-113.

Tilly, C. (2004). Contention and democracy in Europe, 1650-2000. New York: Cambridge University Press. 